\title{
SOME BIOLOGICAL CHARACTERISTICS OF THE DAYSCIAENA ALBIDA (CUVIER 1830) IN LARGEST BRACKISH WATER LAGOON OF INDIA
}

\author{
S.K. Karna and S. Panda* \\ Post-Graduate Department of Zoology, Utkal University \\ Vani Vihar, Bhubaneswar-751004, Orissa, India \\ *Director, Nandankanan Zoological Park, Mayur Bhavan \\ Saheed Nagar, Bhubaneswar, Orissa, India \\ Email: subodhcda@gmail.com
}

\begin{abstract}
An attempt to study length-weight relationship (LWR), condition factor and reproductive aspects of Daysciaena albida was done in Chilika lagoon over one year. The fish specimens for the biological study were collected from landing centers of central and northern sector during pre-monsoon, monsoon and post-monsoon seasons. The LWR from total length and body weight were computed both by sex and seasons. The equations found from the relationships were $y=0.010 x^{2.992}$ for male, $\mathrm{y}=0.010 \mathrm{x}^{2.998}$ for female and $\mathrm{y}=0.010 \mathrm{x}^{2.996}$ as unsexed specimens. The highest condition factor $(\mathrm{K})$ value was recorded during monsoon $(1.42 \pm 0.08)$ followed by post-monsoon $(1.4 \pm 0.09)$ and the lowest $(0.92 \pm 0.11)$ during pre-monsoon seasons. The mean condition factor was registered as $1.06 \pm 0.09$ in all the seasons of unsexed specimens. Among sex, males registered slightly higher $\mathrm{K}$ value than females. For reproductive study, maturation stages, gonad somatic index (GSI) and gastro somatic index (GaSI) were analyzed seasonally. Considering maturation stages highest maturation stages (stages 4 to 7) obtained during pre-monsoon season (in both sexes) which are considered as matured conditions for fish. The highest GSI was registered during pre-monsoon followed by postmonsoon and the lowest was during monsoon season among both the sexes. The GaSI value was lowest during pre-monsoon among males and gradually increased during monsoon and postmonsoon. But in case of female, lowest value was during monsoon and again increased afterwards and was highest in pre-monsoon.
\end{abstract}

Key words: Daysciaena albida, length weight relationship, condition factor, gonado-somatic index, gastro-somatic index, Chilika lagoon.

\section{INTRODUCTION}

The length-weight relationship of fish is an important fishery resource management tool and also useful for comparing life history and morphological aspects of populations inhabiting different regions (Goncalves et al. 1997). Its importance is pronounced in estimating the average weight at a given length group (Beyer 1987) and in assessing the relative well being of a fish population (Bolger and Connoly 1989). 
Condition factor compares the wellbeing of a fish and is based on the hypothesis that heavier fish of a given length are in better condition (Bagenal and Tesch 1978). Conditions factor has been used as an index of growth and feeding intensity (Fagade 1979). Condition factor decrease with increase in length (Bakare 1970, Fagade 1979); and also influence the reproductive cycle in fish (Welcome 1979). Condition factors of different species of sciaenid fish have also been reported (Jayasankar 1990, 1994; Sharma and Ansari 2010, Omogoriola et al. 2011).

Among all parameters in reproductive biology, breeding season and area, age at maturity, age at first reproduction and fecundity are very important (Jakobsen et al. 2009). One of the most important aspects for the sustainable use and management of living marine resources is the maintenance of vital rates that will produce the highest level of resilience. The vital rates are of great importance to reproductive success, which depends on both fishing yield and population maintenance. In this context, understanding the parameters that characterize reproductive processes can help sustainability and management of the stocks (Mace 1993). Sexual maturation has been known to be associated with physiological and behavioral changes in fish.

Dayscieaena albida ("Boroga" as local name) is an economically very important fish species for Chilika lagoon. But this species becomes gradually insufficient in the captures of the fishermen in Chilika lagoon. So, for sustainability and resource management point of view, the study of reproductive biology and other aspects is very necessary. Here, we attempt to analyze some of the biological aspects like length-weight relationship, condition factor, the reproductive behavior of $D$. albida in Chilika lagoon which will be helpful for the future management of the stocks.

\section{MATERIALS AND METHODS}

\section{Study area}

Chilika lagoon, the largest brackish water lagoon of India lies in the east coast region. The lagoon is situated between latitudes $19^{\circ} 28^{\prime}$ and $19^{\circ} 54^{\prime} \mathrm{N}$ and longitude $85^{\circ} 05^{\prime}$ and $85^{\circ} 38^{\prime} \mathrm{E}$. It is designated as an important Ramsar site (No. 229) of the country. The water spread area of the lagoon varies between $906 \mathrm{~km}^{2}$ to $1165 \mathrm{~km}^{2}$ during summer and monsoon, respectively. The estuarine lagoon is a unique assemblage of marine, brackish and fresh water ecosystems. The lagoon is divided into four ecological sectors namely, the southern sector, the central sector, the northern sector and the outer channel area. Basically, the northern sector is fresh water dominated zone while central sector is brackish water zone. Southern sector is higher saline area but the outer channel sector is marine in nature with saline water but during monsoon, the water becomes fresh due to discharge of flood water to the sea from various rivers entering in the northern sector area.

\section{Specimen collection}

The fish specimens for the biological study were collected on monthly basis from Balugaon landing center of central sector and Kalupadaghat landing center of northern sector during premonsoon (March-June 2008), monsoon (JulyOctober 2008) and post-monsoon (November 2008-February 2009) seasons over one year. The specimens were collected of size above $20 \mathrm{~cm}$ in fresh condition from the fishing boats. Collected specimens were caught by khonda nets (fixed nets) and gill nets. After collection, samples were transported to the research laboratory in polythene bags for measurement of total length, body weight and gonad analysis. Total length (TL) and body weight $(\mathrm{BW})$ were measured to the nearest $0.1 \mathrm{~cm}$ and $0.01 \mathrm{~g}$, respectively of the fresh samples. 


\section{Length-Weight relationship (LWR) and condition factor $(\mathbf{K})$}

The length-weight relationship (LWR) for the species was estimated from total length and body weight by the equation (Pauly 1983),

$\mathrm{W}=\mathrm{aL}^{\mathrm{b}}$

Where, ' $\mathrm{W}$ ' is body weight $(\mathrm{g})$, ' $\mathrm{L}$ ' is length (cm), 'a' is constant (intercept) and 'b' is the length exponent (slope) or growth co-efficient. The "a" and "b" values were obtained from exponential regression of the length and weight of fish. The correlation $\left(\mathrm{r}^{2}\right)$, that is the degree of association between the length and weight was computed from the regression analysis, where $R=r^{2}$.

Condition factor was calculated using the equation (Ricker 1975),

\section{$\mathrm{K}=100 \mathrm{~W} / \mathrm{L}^{\mathrm{b}}$}

Where, ' $\mathrm{K}$ ' is condition factor, ' $\mathrm{W}$ ' is body weight and ' $\mathrm{L}$ ' is length, and ' $\mathrm{b}$ ' is exponent from LWR.

\section{Gonad-Somatic index (GSI) and Gastro- Somatic index (GaSI)}

After taking length and weight data, the sampled fish were dissected and the sexes were examined. Stages of maturity of the gonads were observed visually according to the description of Pollard (1972) (Table 1), and the gonad weight, gut weight and the body weight without gut were recorded using electronic balance. Then, the gonad somatic index (GSI) and gastro somatic index (GaSI) were calculated from the body weight, gonad weight and gut weight;

$$
\begin{aligned}
& \text { GSI }=\frac{\text { Gonad weight }(\mathrm{g})}{\text { Body weight without gut }(\mathrm{g})} \times 100 \\
& \text { GaSI }=\frac{\text { Gut weight }(\mathrm{g})}{\text { Body weight }(\mathrm{g})} \times 100
\end{aligned}
$$

In total, 193 fish specimens were examined for their maturity stages, GSI and GaSI.

\section{RESULTS AND DISCUSSION}

The regression equations from length and body weight were computed both by sex and seasons. LWR showed that the values were isometric in both the conditions of season and sex. Their growths were positively allometric. In all cases, growth co-efficient (b value) observed in between 2.5 to 3.5 or nearer to 3 (Table 2) which proves an ideal conditions for the species (Allen 1938). Length-weight relationship gives information on the condition and growth patterns of fish (Bagenal and Tesch 1978). Fish are said to exhibit isometric growth when length increases in equal proportion with body weight for constant specific gravity. The regression co-efficient for isometric growth is ' 3 ' and values greater or lesser than ' 3 ' indicate allometric growth (Gayando and Pauly 1997).

However, the ' $b$ ' value is slightly higher during pre-monsoon season among both male and female, which probably for higher gonad development of the specimens (Table 4). In the above periods, body weight registered more as compared to other seasons among same length specimens. The observation in the present study showed that females were slightly heavier than males of same length which is also agreed by AlGhais (1993). Even though, the variations in 'b'value primarily depends on the shape and fatness of the fish but may also depend upon various other factors like number of specimens examined, condition of the sampling area, food intake (stomach fullness), maturation stages, health condition, etc. but all these factors were not accounted for the present study.

Table 3 shows the seasonal condition factor (K) for D. albida in Chilika lagoon. The highest condition factor $(1.42 \pm 0.08)$ was recorded during monsoon followed by post-monsoon $(1.4 \pm 0.09)$ and the lowest $(0.92 \pm 0.11)$ during pre-monsoon seasons. The mean condition factor registered as $1.06 \pm 0.09$ in all the seasons of unsexed specimens. Among sex, males registered slightly higher $\mathrm{K}$ 
value than females. Here, lowest $\mathrm{K}$ value registered during pre-monsoon, which also consider as the highest gonad development. This also agreed by Vazzoler (1996), who confirmed that lowest K values during the more developed gonad stages might mean resource transfer to the gonads during the reproductive period. The values of the condition factors vary according to seasons and are influenced by environmental conditions. The condition factor of fish, gives information when compared among populations living in certain feeding area, density, climate; when determining the period of gonad maturation; and when following up the degree of feeding activity of a species to verify whether it is making good use of its feeding source (Weatherley 1972). The K-value also reflects information on the physiological state of the fish in relation to its welfare. From a nutritional point of view, there is accumulation of fat and gonad development (LeCren 1951) and in reproductive point of view, highest $\mathrm{K}$ values are reached in some species.

Table 1. Maturity stages and macroscopic descriptions of gonads (Pollard 1972).

\begin{tabular}{|c|c|c|c|c|c|c|c|c|c|}
\hline \multicolumn{2}{|c|}{ Maturity stages } & \multicolumn{8}{|c|}{ Definition } \\
\hline \multicolumn{2}{|c|}{ Stage 1 (immature) } & \multicolumn{8}{|c|}{ Testis or ovary is thin and transparent. It is difficult to distinguish male and female. } \\
\hline \multicolumn{2}{|c|}{ Stage 2 (initial developing) } & \multicolumn{8}{|c|}{$\begin{array}{l}\text { Testis is thin, string-like, and grayish transparent. Ovary is a bit swollen and } \\
\text { transparent. It is not possible to observe eggs with eye. }\end{array}$} \\
\hline \multicolumn{2}{|c|}{ Stage 3 (developing) } & \multicolumn{8}{|c|}{$\begin{array}{l}\text { Testis is swollen, whitish, and smooth. Ovary is swollen and light yellowish. It is } \\
\text { possible to observe eggs with eye. }\end{array}$} \\
\hline \multicolumn{2}{|c|}{ Stage 4 (maturing) } & \multicolumn{8}{|c|}{$\begin{array}{l}\text { Testis is enlarged, whitish, and smooth. Ovary is enlarged, yellowish. Eggs become } \\
\text { bigger. }\end{array}$} \\
\hline \multicolumn{2}{|c|}{ Stage 5 (mature) } & \multicolumn{8}{|c|}{$\begin{array}{l}\text { Testis occupies most of body cavity. It is milky white and smooth. Ovary occupies } \\
\text { most of body cavity. Its color is yellow. Eggs are big. }\end{array}$} \\
\hline \multicolumn{2}{|c|}{ Stage 6 (fully matured) } & \multicolumn{8}{|c|}{$\begin{array}{l}\text { Testis occupies body cavity. It is white, smooth, and fragile. When press the } \\
\text { abdomen, sperm flows out. Ovary occupies body cavity. Its color is light gold. } \\
\text { When press the abdomen, eggs flows out. }\end{array}$} \\
\hline \multicolumn{2}{|c|}{ Stage 7 (spent) } & \multicolumn{8}{|c|}{ Testis is thin, slackened, and grayish. Ovary is thin, slackened, and transparent. } \\
\hline \multirow{3}{*}{ Period } & \multicolumn{9}{|c|}{ Length Weight Relationship (LWR) } \\
\hline & \multicolumn{3}{|c|}{ Male } & \multicolumn{3}{|c|}{ Female } & \multicolumn{3}{|c|}{ Both sex } \\
\hline & Equation & b value & $R$ value & Equation & b value & $R$ value & Equation & b value & $R$ value \\
\hline Pre-monsoon & $y=6 \mathrm{E}-06 x^{3.084}$ & 3.084 & 0.964 & $y=6 E-06 x^{3.076}$ & 3.076 & 0.956 & $y=0.009 x^{3.029}$ & 3.029 & 0.966 \\
\hline Monsoon & $y=2 E-05 x^{2.885}$ & 2.885 & 0.988 & $y=2 E-05 x^{2.928}$ & 2.928 & 0.989 & $y=0.014 x^{2.912}$ & 2.912 & 0.989 \\
\hline Post-monsoon & $\mathrm{y}=2 \mathrm{E}-05 \mathrm{x}^{2.869}$ & 2.869 & 0.981 & $y=2 E-05 x^{2.932}$ & 2.932 & 0.968 & $y=0.013 x^{2.922}$ & 2.922 & 0.974 \\
\hline All seasons & $y=0.010 x^{2.992}$ & 2.992 & 0.978 & $y=0.010 x^{2.998}$ & 2.998 & 0.964 & $y=0.010 x^{2.996}$ & 2.996 & 0.973 \\
\hline
\end{tabular}


Table 3. Condition factor (K) of $D$. albida during different seasons among male and female.

\begin{tabular}{lcccc}
\hline \multirow{2}{*}{ Seasons } & \multicolumn{3}{c}{ Condition factor $(\mathbf{K})$} & Both sex \\
\hline Pre-monsoon & Parameters & Male & Female & Be \\
& Min-Max & $0.79 \pm 0.09$ & $0.77 \pm 0.09$ & $092 \pm 0.11$ \\
\multirow{2}{*}{ Monsoon } & Mean \pm SE & $0.54-0.98$ & $0.41-0.93$ & $0.48-1.16$ \\
& Min-Max & $1.56 \pm 0.08$ & $1.53 \pm 0.08$ & $1.42 \pm 0.08$ \\
Post-monsoon & Mean \pm SE & $1.42-1.68$ & $1.21-1.57$ & $1.27-1.66$ \\
& Min-Max & $1.64 \pm 0.1$ & $1.37 \pm 0.09$ & $1.40 \pm 0.09$ \\
All seasons & Mean \pm SE & $1.44-1.98$ & $1.15-1.56$ & $1.19-1.67$ \\
& Min-Max & $0.71-1.33$ & $1.06 \pm 0.1$ & $1.06 \pm 0.09$ \\
& & & $0.53-1.25$ & $0.53-1.31$ \\
\hline
\end{tabular}

Table 4. Gonado-somatic index (GSI) and Gastor-somatic index (GaSI) of D. albida.

\begin{tabular}{clccc}
\hline \multirow{2}{c}{ Sex } & \multicolumn{1}{c}{ Parameters } & $\begin{array}{c}\text { GSI and GaSI } \\
\text { Pre-monsoon }\end{array}$ & Monsoon & Post-monsoon \\
\hline Male & Length range $(\mathrm{cm})$ & $20-37.5$ & $21.8-40.2$ & $23.2-43.8$ \\
& Body weight range $(\mathrm{g})$ & $60-522$ & $114-704$ & $136-892$ \\
& GSI & $2.29 \pm 0.36(24)$ & $0.46 \pm 0.07(22)$ & $0.5 \pm 0.06(31)$ \\
& GaSI & $6.25 \pm 0.58(24)$ & $6.29 \pm 0.35(22)$ & $6.58 \pm 0.32(31)$ \\
Female & Length range & $20-50.4$ & $21.3-42.3$ & $25.4-45.2$ \\
& Body weight range & $52-1136$ & $106-806$ & $159-968$ \\
& GSI & $4.13 \pm 0.45(38)$ & $1.16 \pm 0.15(31)$ & $1.34 \pm 0.15(47)$ \\
& GaSI & $9.18 \pm 0.51(38)$ & $7.47 \pm 0.53(31)$ & $7.66 \pm 0.54(47)$ \\
\hline
\end{tabular}

The Gonado-somatic index (GSI) for male and female during pre-monsoon, monsoon and postmonsoon seasons were analyzed (Table 4). The highest GSI registered during pre-monsoon followed by post-monsoon and lowest during monsoon season among both the sexes. So, the results clearly indicated that the pre-monsoon seasons as the reproductive period for the species. After pre-monsoon season, the GSI recorded very low which shows the non-reproductive period and afterwards, GSI again increases. During monsoon, lowest GSI in female suggests that fish can completely spawned and no more gonadal mass lies in the ovary.

The calculation of Gastro-somatic Index (GaSI) is a useful and an efficient way for comparing the scale of feeding (food consumption) during various seasons for determining the environmental and physiological effects on feeding habits. The GaSI value considered lowest during pre-monsoon among males and gradually increases during monsoon and post-monsoon (Table 4). But in case of female, lowest value considered during monsoon and again increases afterwards and highest in pre-monsoon. So, the highest level of GaSI observed before and after spawning (Mohammadizadeh et al. 2010). Here, the value in female is highest during pre-monsoon seasons and is also the highest reproductive periods. So, from the results it is quite strongly recommended that the spawning seasons are late pre-monsoon and early stages of monsoon periods. 


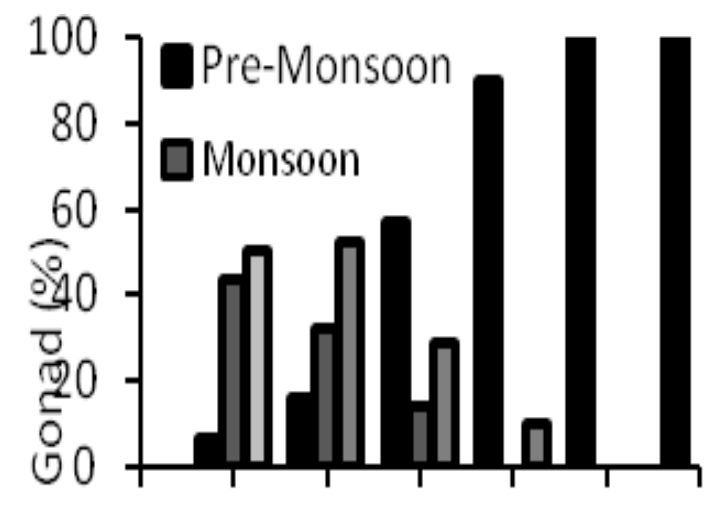

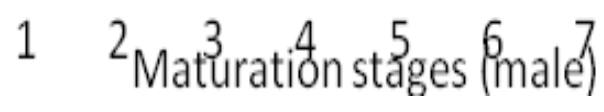

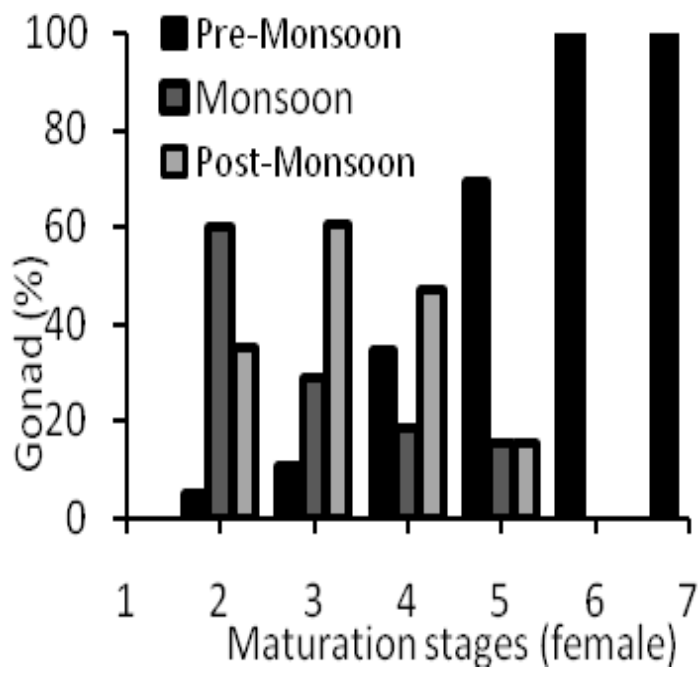

Fig. 1. Seasonal variation of gonad development of $D$. albida.

Considering maturation stages observations of both male and female, significant results were obtained. The highest maturation stages (stages 4 to 7) were obtained which was also considered as matured conditions for fish, during pre-monsoon seasons in both sexes of the species (Fig. 1). Maturation stage 4 was observed in $47 \%$ during post-monsoon followed by $34 \%$ of the specimens during pre-monsoon in females but in male above $50 \%$ (i.e., 57\%) registered during pre-monsoon season. So, we found a clear conclusion from the above observation that males start maturing slightly earlier than females i.e., female maturing in post-monsoon while males in pre-monsoon. In case of maturation stage 5, higher percentages (90\% male and 69\% female) were found during pre-monsoon. Again, fully matured (stage 6 and 7) stages in both sexes were registered during premonsoon season only. Hence, we can conclude from the above observation that $D$. albida shows highest maturation during pre-monsoon only which is also supported by early observations made by Jhingran and Natarajan (1969). The conclusion also supported by the GSI and GaSI results of the present study.

\section{ACKNOWLEDGMENTS}

We are very much thankful to Japan International Cooperation Agency (JICA) and Chilika Development Authority (CDA) for financial assistance. We extend hearty thanks to Chief-Executive, CDA and Dr K. S. Bhatta, Dr R. N. Samal, Scientists of CDA and all researchers for their cooperation and valuable suggestions throughout the study.

\section{REFERENCES}

Al-Ghais, S. 1993. Some aspects of the biology of Siganus canaliculatus in the southern Arabian Gulf. Bull. Mar. Sci. 52(3):886-897.

Allen, K.R. 1938. Some observations on the biology of the trout (Salmo trutta) in Windermere. J. Anim. Ecol. 7:333-349.

Bagenal, T.B. and A.T. Tesch. 1978. Conditions and Growth Patterns in Fresh Water Habitats. Blackwell Scientific Publications, Oxford.

Bakare, O. 1970. Bottom deposits as food of inland fresh water fish. In: Kainji, A Nigerian Manmade Lake. (ed.) Visser, S.A. Kanyi Lake Studies, Vol. 1. Ecology Published for the Nigerian Institute. 
Beyer, J.E. 1987. On Length-weight relationship computing the mean weight of the fish of a given length class. Fishbyte 5(1):11-13.

Bolger, T. and P.L. Connoly. 1989. The selection indices for the measurement and analysis of fish condition. J. Fish Biol. 17(3):1-182.

Fagade, S.O. 1979. Observation on the biology of two species of Tilapia from the Lagos lagoon Nigeria. Bull. Inst. Fond Afr. Nore (Series- A) 41:627-658.

Gayando, F.C. and D. Pauly. 1997. FAO ICLARM Stock Assessment Tools (FISAT): References Manual, FAO Computerized Information Series (Fisheries) 8:262.

Goncalves, J.M.S., L. Bentes, P.G. Lino, J. Ribeiro, A.V.M. Canario and K. Erzini. 1997. Weight-length relationships for selected fish species of the small-scale demersal fisheries of the south and south-west coast of Portugal. Fisheries Research 30:253-256.

Jakobsen, T., M.J. Fogarty, B.A. Megrey and E. Moksness, 2009. Fish Reproductive Biology: Implications for Assessment and Management. Wiley-Blackwell, USA.

Jayasankar, P. 1990. Length weight relationship and relative condition factor in Otouthes ruber (Schneider, 1801) from Gulf of Mannar and Palk Bay. Indian Journal of Fisheries 37(3):261-263.

Jayasankar, P. 1994. Observations on the biology of some sciaenid fishes from Mandapam region. Indian Journal of Fisheries 41(2):8086.

Jhingran, V.G. and A.V. Natarajan. 1969. A study of the fisheries and fish populations of the Chilika Lake during the period 1957-65. J. Inland Fish. Soc. India 1:49-126.

LeCren, E.D. 1951. The length-weight relationship and seasonal cycle in gonad weight and condition in the perch Perca fluviatilis. $J$. Anim. Ecol. 20(2):201-219.

Mace, P.M. 1993. Relationships between common biological reference points used as thresholds and targets of fisheries management strategies. Canadian J of Fish. Aquat. Sci. 51:110-122.

Mohammadizadeh, F., T. Valinassab, S. Jamili, A. Matinfar, A.H. Bahri-Shabanipour and M. Mohammadizadeh. 2010. A study on diet composition and feeding habitats of Sawtooth Barracuda (Sphyraena putnamae) in BandarAbbas (North of Persian Gulf). Journal of Fisheries and Aquatic Science 5(3):179-190.

Omogoriola, H.O., B.B. Solarin, A.B. Williams, C.I. Ayo-Olalusi and B. Edah. 2011. Lengthweight relationships and relative condition factor (Kn) of Sciaenids, Pseudotolithus senegalensis (Valenciennes 1833) and Pteroscion peli (Bleek 1863), in Nigerian coastal water. Internet Journal of Food Safety 13:81-87.

Pauly, D. 1983. Some simple methods for the assessment of tropical fish stock. FAO Fish Tech. Pap. No. 234. 52 pp.

Pollard, D.A. 1972. The biology of a landlocked form of the normally catadromous salmonform fish Galaxias maculates (YENYS) 3. Structure of the gonads. Aust. J. Mar. Freshwater Res. 23:17.

Ricker, W.E. 1975. Computation and Interpretation of Biological Statistics of Fish Populations. Department of Environment, Fisheries and Marine Service, Ottawa, ON. 382 pp.

Sharma, E.F. and Z.A. Ansari. 2010. Study of age and growth of Indian sand whiting, Sillago sihama (Forssakal) from Zuari estuary, Goa. Indian J of Marine Sciences 39(1):68-73.

Vazzoler, A.E. 1996. Biologia da Reproducao de Peixes Teleosteos: Teoria e Pratica. EDUEM, SBI, Maringa, $169 \mathrm{pp}$.

Weatherley, A.H. 1972. Growth and Ecology of Fish Populations. Academic Press, London, 293 pp.

Welcome, R.L. 1979. Fisheries Ecology of Flood Plain Rivers. Longman Press, London, 317 pp. 